\title{
Assessment of Solid Waste Management at Source in Compliance With Guidelines Among Residents of Kawempe Division, Kampala, Uganda
}

\section{Paul Maderu}

Uganda Martyrs University

Kizito Omona ( $\square$ kizitoomona@gmail.com )

Uganda Martyrs University

\section{Research Article}

Keywords: Solid waste management, Compliance, Guidelines, Kampala, Uganda

Posted Date: December 29th, 2021

DOI: https://doi.org/10.21203/rs.3.rs-1191784/v1

License: (c) (i) This work is licensed under a Creative Commons Attribution 4.0 International License.

Read Full License 


\section{Abstract}

Background: Solid waste management poses a big challenge for many urban households, municipalities and cities, especially in developing countries, partly due to increasing urbanization. Overcrowding and informal settlements have emerged with illegal and indiscriminate waste disposal. Guidelines for proper management of solid waste are least observed at house hold level in such settings. The purpose of the study was to assess solid waste management at source in compliance with guidelines among residents of Kawempe municipality Kampala district.

Methods: It was descriptive and analytical cross-sectional study design, with both quantitative and qualitative methods. 385 households heads and four local leaders were interviewed using researcher administered questionnaires and interview guide.

Results: The study found that only $37.9 \%$ of households complied with guidelines for solid waste management at source. Factors of waste management practices were waste reduction $(p=0.005)$, separation $(p=0.001)$, reuse $(p=0.001)$ and composting $(p=0.027)$. Determinants such as gender $(p=0.007)$, marital status $(p=0.016)$, level of education $(p<0.0001)$, occupation $(p=0.007)$, household size $(p=0.025)$, medium of community sensitization ( $p<0.0001)$, enforcement of bi-laws $(p=0.005)$, type of waste generated $(p<0.0001)$ and waste storage method $(p=0.009)$ were implicated.

Conclusion: Compliance with guidelines in the management of household solid waste at source was still very low within the city. Authorities ought to intensify household solid waste management awareness campaigns.

\subsection{Background}

Solid waste management (SWM) poses a big challenge for many urban households, municipalities and cities at large especially in the low income countries as a result of increasing urbanization (Mukama et al., 2016). It is projected that Sub-Saharan Africa will be the world's fastest-growing region for waste generation by 2050 due to increasing urbanization, yet it is poorly planned with inefficient solid wastes management strategies (Bello, et. al., 2016 and Aryampa, et. al., 2019). In Kampala city, about 54\% of the population in live in crowded and slum areas located mostly in low-lying zones and in wetlands with inevitable development of unplanned informal settlements and consequently illegal and indiscriminate waste disposal methods. These poor waste management strategies predispose households to environmental and health hazards including waterborne diseases such as typhoid, diarrhea, hepatitis and respiratory ailments (Cruvinel et al., 2019). Household solid waste include refuse of day-to-day leaving mainly organic biodegradable wastes, including peelings from raw foods, fruit and vegetables, food remains and leaves, paper, textile and yard waste (Komakech et al., 2014), and partially degradable waste like disposable napkins, wood and sanitary residues, and non-degradable waste including plastics, leather, rubbers, glass, metal and electronic waste. 
Most developing economies in low-income countries like Uganda have refined policies for SWM but residents reluctantly comply due to lack of enforcement of the policies/by-Laws and inadequate public education and awareness (Al-Khatib et al., 2010) cited in (McAllister, 2015). A study by Wadehra and Mishra (2017) in Delhi revealed a clear disconnect between the formulated household SMW guidelines by the authorities, the information being delivered to households and their practice in compliance with the guidelines. Whereas the guidelines and the knowledge of negative effects should be enabling the community members to reduce the generation of waste at source and to ensure proper disposal, individual households waste disposal practices largely don't conform to guidelines (Ishfaq, Puneet and Sukhwinder, 2021).

The Study had the following specific objectives

i. To investigate the solid waste management practices at source associated with compliance with guidelines among residents of Kawempe Division, Kampala District

ii. To establish socio-demographic determinants of solid waste management at source in compliance with guidelines among residents of Kawempe division Kampala District

iii. To determine the attitudes about solid waste management at source in compliance with guidelines among residents of Kawempe division Kampala District

iv. To examine the barriers of solid waste management at source affecting compliance with guidelines among residents of Kawempe Division, Kampala District

\subsection{Methods}

\subsection{Study Design}

A descriptive and analytical cross-sectional study design was used with both quantitative and qualitative techniques, hence a mixed methods study.

\subsection{Study Population}

All households of Kawempe division preferably the heads of the respective households and the key informants were chosen among local council leaders.

\subsection{Sample Size}

Cochran formula for large populations (Cochran, 1977) was used:

$$
n_{0}=\frac{Z^{2} p q}{e^{2}}
$$


Where: $\mathrm{n}_{0}=$ the required sample size

$Z^{2}=$ the abscissa of the normal curve that cuts off an area $a$ at the tails ( 1 - a equals the desired confidence level, $95 \%$ in this study) $=1.96$,

$e=$ the level of precision (error), set at $5 \%$ or 0.05 for this study,

$p=$ estimated proportion of compliance with guidelines among households. We used a statistically conservative prevalence of $50 \%$ compliance with guidelines.

$q=1-p$.

Thus, $n_{0}=385$ households heads

\subsection{Sampling Technique}

The sample size was distributed proportionately across all the Parishes in Division. The number of households in each of the Parishes were obtained from the Division offices and the sample from each parish was expressed as a proportion of the total study sample to obtain the number of respondents from each parish. The sampling interval for each parish was got by dividing the number of households by the sample from that particular parish. Systematic random sampling was then used where the pre-determined number of respondents per parish was attained. First respondent from each parish was selected randomly.

\subsection{Data Collection Tools and Methods}

A researcher-administered semi-structured questionnaire, an observational check list and interview guides for key informants were used. Both open and closed ended questions were included.

\subsection{Data Entry, Analysis and Presentation}

For quantitative data, the collected data were entered into Microsoft office excel 2019 for editing and cleaning then into STATA for analysis. Descriptive statistics was analyzed and presented in terms of frequencies and percentages in tables. The Chi-square test was used to determine the association between the two variables through bivariate analysis while odds ratios was used for the measure of association between the predictor and outcome variables for inferential statistics. Qualitative data were coded and transcribed, generating themes and sub-themes that were analyzed.

\subsection{Ethical Approval}

The required country ethical approval for the study was sought. Uganda Martyrs University Research Ethics Committee was quite helpful in the clearance. All other ethical requirements in research with human 


\subsection{Results}

\subsection{Socio-demographic characteristics of the participants}

Table 1 summarizes the socio-demographic characteristics. Majority of the respondents (50.4\%), were aged 30 years above, $67.5 \%$ were female and $41.8 \%$ were either married or cohabiting. Most participants (52\%) were of secondary level of education and only $1.3 \%$ had never attained school education. $28.1 \%$ of respondents were of the protestant religion, $59.7 \%$ lived with families of less than five and $46.8 \%$ had been residents for one to five years.

Table 1: Socio-demographic characteristics of the participants

Socio-demographic Variables

Age in years

- $<30$

- $>=30$

Gender

- Female

- Male

Marital status

- Divorced/separated/widowed

- Married/cohabiting

- Others

- Single

Highest level of education

- Primary

- Secondary

- Tertiary

- Never schooled

Religion

- Born again

- Catholic

- Muslim

- Others

- Protestant

Number of people living in the house

- $<5$

- $5-10$

- $>10$

Duration lived in the place

- $<1$ year

- 1-5years

- 6-10 years

- >10 years

\section{Frequency Percentage}

191

49.6

50.4

260

125

67.5

32.5

91

161

1

132

23.6

41.8

0.3

34.3

76

200

104

$82 \quad 21.3$

$85 \quad 22.1$

$103 \quad 26.7$

$8 \quad 2.0$

$108 \quad 28.1$

230

59.7

150

5

71

39

1.3

18.4

46.8

18.2

16.6 


\subsection{Solid Waste Management Practices Associated with Compliance with Guidelines}

Compliance with guidelines was measured by scoring the respondent's solid waste management practices against each of the following six standards; waste reduction, separation, re-use, recycling, composting and responsible disposal, table 2 . Bivariate analysis was made between the practice variable and compliance with guidelines. The chi square test was done to obtain crude odds ratios between the independent variables and the outcome variable. Statistically significant independent variables at bivariate analysis were then subjected to a multi-variable logistics regression model to test for their significance, table 3.

\section{Table 2: Solid waste management practices in compliance with guidelines}




\begin{tabular}{|c|c|c|c|c|c|}
\hline \multirow[t]{2}{*}{ Waste Management Variables } & \multicolumn{2}{|c|}{$\begin{array}{l}\text { Compliance with } \\
\text { Guidelines }\end{array}$} & \multirow[t]{2}{*}{ Total } & \multirow[t]{2}{*}{$\begin{array}{l}\text { COR }(95 \% \\
\text { CI: L-U) }\end{array}$} & \multirow[t]{2}{*}{$p$-value } \\
\hline & $\begin{array}{l}\text { Complied } \\
\text { (146) }\end{array}$ & $\begin{array}{l}\text { Didn't } \\
\text { comply } \\
\text { (239) }\end{array}$ & & & \\
\hline \multicolumn{6}{|l|}{$\begin{array}{l}\text { Taking shopping basket or bag } \\
\text { when shopping }\end{array}$} \\
\hline - Always & $97(66.4 \%)$ & $149(62.3 \%)$ & 246 & 1.0 & 0.005 \\
\hline - Most of the times & $34(23.3 \%)$ & $35(14.6 \%)$ & 69 & $0.5(0.3-1)$ & \\
\hline : Never & $\begin{array}{l}0(0 \%) \\
100 \%)\end{array}$ & $2(0.8 \%)$ & 2 & $0.4(0.2-0.8)$ & \\
\hline - Rarely & $14(9.6 \%)$ & $41(17.2 \%)$ & 55 & $4.1(0.5-34.4)$ & \\
\hline \multicolumn{6}{|l|}{$\begin{array}{l}\text { Do separate solid waste you } \\
\text { generate at home }\end{array}$} \\
\hline No & $92(63 \%)$ & $189(79.1 \%)$ & 281 & 1.0 & 0.001 \\
\hline - Yes & $54(37 \%)$ & $50(20.9 \%)$ & 104 & $2.2(1.4-3.5)$ & \\
\hline \multicolumn{6}{|l|}{$\begin{array}{l}\text { Reuse of solid waste generated at } \\
\text { home }\end{array}$} \\
\hline - No & $16(11 \%)$ & $60(25.1 \%)$ & 76 & & 0.001 \\
\hline - Yes & $133(89 \%)$ & $176(74.9 \%)$ & 309 & $2.7(1.5-4.9)$ & \\
\hline \multicolumn{6}{|l|}{$\begin{array}{l}\text { If yes, which of solid waste } \\
\text { - Cardboard, pappers and food }\end{array}$} \\
\hline $\begin{array}{l}\text { - Cardboard, papers and food } \\
\text { leftovers }\end{array}$ & $56(42.7 \%)$ & $79(44.4 \%)$ & 135 & 1.0 & 0.002 \\
\hline - Food leftover & $10(7.6 \%)$ & $8(4.5 \%)$ & 18 & $0.9(0.3-2.4)$ & \\
\hline - Food leftover and bottles & $58(44.3 \%)$ & $59(33.2 \%)$ & 117 & $0.3(0.1-0.7)$ & \\
\hline - Plastics bottles & $6(4.6 \%)$ & $31(17.4 \%)$ & 37 & $0.2(0.1-0.5)$ & \\
\hline $\begin{array}{l}\text { Plastics and glasses } \\
\text { Do you recycle solid waste }\end{array}$ & $1(0.8 \%)$ & $1(0.6 \%)$ & 2 & & \\
\hline - No & $141(96.6 \%)$ & $235(98.3 \%)$ & 376 & & 0.310 \\
\hline - Yes & $5(3.4 \%)$ & $4(1.7 \%)$ & 9 & $2.1(0.5-7.9)$ & \\
\hline \multicolumn{6}{|l|}{$\begin{array}{l}\text { Do you compost some of your } \\
\text { solid waste }\end{array}$} \\
\hline - No & $127(87 \%)$ & $224(93.7 \%)$ & 351 & & 0.027 \\
\hline - Yes & $19(13 \%)$ & $15(6.3 \%)$ & 34 & $2.2(1.1-4.5)$ & \\
\hline \multicolumn{6}{|l|}{ If no, what are the reasons } \\
\hline - I don't know how to compost & $26(21.0 \%)$ & $59(26.7 \%)$ & 85 & & 0.040 \\
\hline - Lack space & $27(21.0 \%)$ & $33(14.0 \%)$ & 60 & $0.6(0.3-1.6)$ & \\
\hline $\begin{array}{l}\text { - Lack space and I don't know } \\
\text { to compost }\end{array}$ & $13(10.5 \%)$ & $47(21.3 \%)$ & 60 & $1.8(0.7-4.1)$ & \\
\hline - Lack of space and no nearby & $36(29.0 \%)$ & $48(21.7 \%)$ & 84 & $0.5(1.3-0.6)$ & \\
\hline $\begin{array}{l}\text { composing facility } \\
\text { - Lack of space and not } \\
\text { interested in composting }\end{array}$ & $9(7.3 \%)$ & $18(8.1 \%)$ & 27 & & \\
\hline No nearby composting facility & $17(11.3 \%)$ & $18(8.1 \%)$ & 35 & & \\
\hline $\begin{array}{l}\text { Is there solid waste whose final } \\
\text { disposal is within your home }\end{array}$ & & & & & \\
\hline - No & $43(29.5 \%)$ & $102(42.7 \%)$ & 145 & & 0.010 \\
\hline - Yes & $103(70.6 \%)$ & $137(57.3 \%)$ & 240 & $1.7(1.2-2.8)$ & \\
\hline \\
\hline - Food remains & $17(16.7 \%)$ & $18(13 \%)$ & 35 & & $<0.0001$ \\
\hline $\begin{array}{l}\text { Food remains and plastic } \\
\text { waste }\end{array}$ & $3(2.9 \%)$ & $11(8.0 \%)$ & 14 & $0.1(0.02-0.02)$ & \\
\hline - Garden yard waste & $5(4.9 \%)$ & $17(12.3 \%)$ & 22 & $0.1(0.1-0.69)$ & \\
\hline - Garden yard and food remains & $76(74.5 \%)$ & $75(54.4 \%)$ & 151 & $0.01(0.01-0.5)$ & \\
\hline - Plastics waste & $1(1.0 \%)$ & $17(12.3 \%)$ & 18 & & \\
\hline \multicolumn{6}{|l|}{$\begin{array}{l}\text { How do you carry out final } \\
\text { dispersal }\end{array}$} \\
\hline - Open burning & $36(35.0 \%)$ & $63(46.3 \%)$ & 99 & & 0.005 \\
\hline - Use as animal feed & $5(4.9 \%)$ & $15(11 \%)$ & 20 & $1.7(0.9-2.9)$ & \\
\hline $\begin{array}{l}\text { - Use as animal feed and open } \\
\text { buming }\end{array}$ & $7(6.8 \%)$ & $6(4.4 \%)$ & 13 & $1.2(0.6-2.3)$ & \\
\hline - Use animal and poultry feeds & $20(19.4 \%)$ & $9(6.6 \%)$ & 29 & $0.1(0.1-1)$ & \\
\hline - Use as poultry feed & $13(12.6 \%)$ & $17(12.5 \%)$ & 30 & $0.6(0.3-1.3)$ & \\
\hline $\begin{array}{l}\text { Use as poultry feeds and open } \\
\text { buming }\end{array}$ & $16(15.5 \%)$ & $25(18.4 \%)$ & 41 & & \\
\hline Others & $6(5.8 \%)$ & $2(0.7 \%)$ & 8 & & \\
\hline $\begin{array}{l}\text { Do u have access to solid waste } \\
\text { collection service at home }\end{array}$ & & & & & \\
\hline No & $62(42.5 \%)$ & $74(31.0 \%)$ & 136 & $1.0(0.4-0.9)$ & 0.028 \\
\hline - Yes & $84(57.5 \%)$ & $165(69.0 \%)$ & 249 & & \\
\hline
\end{tabular}


Study findings indicate that only $146(37.9 \%)$ of the households complied with guidelines in managing their solid waste at source. From table 4 above, solid waste reduction $(p=0.005)$, separation $(p=0.001)$, reuse $(p=0.001)$, composting $(p=0.002)$ and responsible disposal $(p=0.027)$ were all statistically significant factors of household solid waste management practices.

Majority of participants, $63.9 \%$, always took a shopping bag while going shopping but only $39.4 \%$ of these complied with general guidelines. $0.5 \%$ never carried a shopping bag while going shopping. Most of the households (73\%) did not practice solid waste separation at source. Those who separated their waste were 2.2 times more likely to comply with guidelines compared with those who did not (Crude odds ratio (COR): 2.2, Cl: 1.4-3.5). 80.3\% of participants practiced re-use of some of the generated solid waste although, $57 \%$ of these failed to comply with general guidelines. Those who practiced re-use of some waste were 2.7 times more likely to comply with guidelines compared with those who did not practice (COR: 2.7, Cl: 1.5-4.9).

Also, only $8.8 \%$ of households practice composting of some of the solid waste and most of these (55.9\%) complied with general guidelines. Majority of those who did not practice composting $(24.6 \%, p=0.040)$, did not have knowledge of solid waste composting. Although $41.1 \%$ of households practiced open burning as a solid waste disposal method, those who used the waste as animal feeds were 1.7 times more likely to comply with guidelines compared with those who practiced open burning (COR: 1.7, Cl: 0.9-2.9, p=0.005).

Table 3: Multivariable logistics regressionshowing compliance with guidelines

\begin{tabular}{|c|c|c|c|c|}
\hline Variable & $\begin{array}{l}\text { Adjusted } \\
\text { ratios }\end{array}$ & odd & $\begin{array}{c}95 \% \mathrm{CI} \\
\mathrm{L}-\mathrm{U}\end{array}$ & $p$-value \\
\hline \multicolumn{5}{|l|}{ Gender } \\
\hline - Female & 1.0 & & & \\
\hline - Male & 1.9 & & $1.21-3.04$ & 0.006 \\
\hline \multicolumn{5}{|c|}{ Highest level of education } \\
\hline - Primary & 1.0 & & & \\
\hline - Secondary & 1.3 & & $0.13-12.04$ & 0.839 \\
\hline - Tertiary & 1.9 & & $0.21-17.58$ & 0.561 \\
\hline - Never schooled & 5.9 & & $0.64-54.7$ & 0.118 \\
\hline \multicolumn{5}{|c|}{ Taking shopping basket or bag when shopping } \\
\hline - Always & 1.0 & & & \\
\hline - Most of the times & 1.9 & & $0.99-3.68$ & 0.055 \\
\hline - Never & 2.8 & & $1.32-6.14$ & 0.008 \\
\hline - Rarely & $\mathrm{N} / \mathrm{A}$ & & & 0.999 \\
\hline - Sometimes & 0.2 & & $0.01-2.05$ & 0.194 \\
\hline \multicolumn{5}{|c|}{ Do separate solid waste you generate at home } \\
\hline - No & 1.0 & & & \\
\hline - Yes & 0.4 & & $0.28-0.71$ & 0.001 \\
\hline \multicolumn{5}{|c|}{ Reuse of solid waste generated at home } \\
\hline - No & 1.0 & & & \\
\hline - Yes & 0.4 & & $0.21-0.68$ & 0.001 \\
\hline
\end{tabular}

\subsection{Socio-demographic determinants of Solid Waste Management in Compliance with Guidelines}


Determinants of compliance with guidelines in the management of solid waste at household level were established by asking related questions to participants and examining their socio-demographic characteristics. After entering responses in STATA, bivariate analysis was done, table 4 .

\section{Table 4: Socio-demographic determinants of solid waste management in compliance with guidelines}

\begin{tabular}{|c|c|c|c|c|c|}
\hline \multirow[t]{2}{*}{ Socio-demographic Variables } & \multicolumn{2}{|c|}{ Compliance with guidelines } & \multirow[t]{2}{*}{ Total } & \multirow{2}{*}{$\begin{array}{l}\text { COR }(95 \% \\
\text { CI: L - U) }\end{array}$} & \multirow[t]{2}{*}{$p$-value } \\
\hline & $\begin{array}{l}\text { Complied } \\
(146)\end{array}$ & $\begin{array}{l}\text { Didn't } \\
\text { comply } \\
\text { (239) }\end{array}$ & & & \\
\hline \multicolumn{6}{|l|}{ Age (years) } \\
\hline - $\quad<30$ & $63(43.2 \%)$ & $128(53.6 \%)$ & 191 & 1.0 & 0.059 \\
\hline - $>=30$ & $83(56.9 \%)$ & $111(46.4 \%)$ & 194 & $1.5(1-2.3)$ & \\
\hline \multicolumn{6}{|l|}{ Gender } \\
\hline - Female & $111(76.0 \%)$ & $149(62.3 \%)$ & 260 & 1.0 & 0.007 \\
\hline - Male & $35(24.0 \%)$ & $90(37.7 \%)$ & 125 & $0.5(0.3-0.8)$ & \\
\hline \multicolumn{6}{|l|}{ Marital status } \\
\hline - Divorced/separated/widowed & $39(26.7 \%)$ & $52(21.8 \%)$ & 91 & 1.0 & 0.016 \\
\hline - Married/cohabiting & $70(48.0 \%)$ & $91(38.1 \%)$ & 161 & $0.5(0.3-0.9)$ & \\
\hline - Others & $0(0.0 \%)$ & $1(0.4 \%)$ & 1 & $0.5(0.3-0.8)$ & \\
\hline - Single & $37(25.3 \%)$ & $95(39.8 \%)$ & 132 & & \\
\hline \multicolumn{6}{|l|}{ Highest level of education } \\
\hline - Primary & $18(12.3 \%)$ & $58(24.3 \%)$ & 76 & 1.0 & $<0.0001$ \\
\hline - Secondary & $65(44.5 \%)$ & $135(56.5 \%)$ & 200 & $5.9(0.6-54.7)$ & \\
\hline - Tertiary & $62(42.5 \%)$ & $42(17.6 \%)$ & 104 & $4.7(2.5-9.2)$ & \\
\hline - Never & $1(0.7 \%)$ & $4(1.7 \%)$ & 5 & $3.1(1.9-5.1)$ & \\
\hline \multicolumn{6}{|l|}{ Major occupation } \\
\hline - Business & $78(53.4 \%)$ & $140(58.6 \%)$ & 218 & 1.0 & 0.007 \\
\hline - Causal occupational & $14(9.6 \%)$ & $25(10.5 \%)$ & 39 & $0.5(0.2-1.1)$ & \\
\hline - Farming & $12(8.2 \%)$ & $11(4.6 \%)$ & 23 & $0.5(0.2-1.3)$ & \\
\hline - Others & $2(1.4 \%)$ & $7(2.9 \%)$ & 9 & $0.3(0.1-0.7)$ & \\
\hline - Professional & $31(21.2 \%)$ & $24(10.0 \%)$ & 55 & $0.9(0.2-5.6)$ & \\
\hline - Student & $9(6.2 \%)$ & $32(13.4 \%)$ & 41 & $0.2(0.1-0.5)$ & \\
\hline \multicolumn{6}{|l|}{$\begin{array}{l}\text { Number of people living in the } \\
\text { house }\end{array}$} \\
\hline - $\quad<5$ & $75(51.4 \%)$ & $155(64.9 \%)$ & 230 & 1.0 & 0.025 \\
\hline - $5-10$ & $69(47.3 \%)$ & $81(33.9 \%)$ & 150 & $1.8(1.2-2.7)$ & \\
\hline - $>10$ & $2(1.4 \%)$ & $3(1.3 \%)$ & 5 & $1.3(0.2-7.9)$ & \\
\hline \multicolumn{6}{|l|}{ If yes, how } \\
\hline - Over radio and television & $82(56.6 \%)$ & $64(26.9 \%)$ & 146 & 1.0 & $<0.0001$ \\
\hline - Over radio & $60(41.4 \%)$ & $150(63.0 \%)$ & 210 & $0.2(0.01-3.3)$ & \\
\hline - Over television & $4(2.1 \%)$ & $19(8.0 \%)$ & 23 & $0.1(0.04-0.4)$ & \\
\hline - Others & $0(0.0 \%)$ & $6(2.1 \%)$ & 6 & $0.4(0.1-1.4)$ & \\
\hline \multicolumn{6}{|l|}{$\begin{array}{l}\text { Enforcement of proper solid } \\
\text { waste management by leaders }\end{array}$} \\
\hline - Once a week & $52(35.6 \%)$ & $88(36.8 \%)$ & 140 & 1.0 & 0.005 \\
\hline - Once a month & $76(52.1 \%)$ & $92(38.5 \%)$ & 168 & $0.7(1.3-0.4)$ & \\
\hline - After every three months & $8(5.5 \%)$ & $39(16.3 \%)$ & 47 & $0.2(0.01-2.3)$ & \\
\hline - After every six months & $3(2.1 \%)$ & $4(1.7 \%)$ & 7 & $0.4(0.1-1.2)$ & \\
\hline $\begin{array}{l}\text { Have never seen them } \\
\text { enforce }\end{array}$ & $2(1.4 \%)$ & $1(0.4 \%)$ & 3 & $0.6(0.2-1.6)$ & \\
\hline - Others & $5(3.4 \%)$ & $15(6.3 \%)$ & 20 & & \\
\hline \multicolumn{6}{|l|}{ Type of solid waste } \\
\hline - Garden yard and peelings & $1(0.7 \%)$ & $16(6.7 \%)$ & 17 & 1.0 & $<0.0001$ \\
\hline - Plastics, garden yard, & $99(67.8 \%)$ & $113(47.3 \%)$ & 212 & & \\
\hline $\begin{array}{l}\text { peelings and food waste } \\
\text { - Plastics }\end{array}$ & $2(1.4 \%)$ & $15(6.3 \%)$ & 17 & $6.7(0.9-1.9)$ & \\
\hline - Plastics and paper & $0(0.0 \%)$ & $5(2.1 \%)$ & 5 & $0.5(0.3-0.7)$ & \\
\hline
\end{tabular}


- Plastic, paper, food waste

- Plastics, garden yard and peelings

How do you store solid waste

- Plastic bags

- Plastic bag, waste bucket and others

- Plastic bag and open pile outside

- Waste basket and open container

- Plastic bags and cardboard box

- Others

$\begin{array}{lllll}4(2.7 \%) & 12(5.0 \%) & 16 & & \\ 40(27.4 \%) & 78(32.6 \%) & 118 & & \\ & & & & \\ 67(45.9 \%) & 154(64.4 \%) & 221 & 2.0 & 0.009 \\ 7(4.8 \%) & 8(3.4 \%) & 15 & & \\ 15(10.3 \%) & 11(4.6 \%) & 26 & & \\ 3(2.1 \%) & 2(0.8 \%) & 5 & & \\ 5(3.4 \%) & 3(1.3 \%) & 8 & & \\ 1(0.7 \%) & 2(0.8 \%) & 3 & & \\ 48(32.9 \%) & 59(24.7 \%) & 107 & \end{array}$

From table 4 , gender $(p=0.007)$, marital status $(p=0.016)$, highest level of education $(p<0.0001)$, major occupation ( $p=0.007)$, number of people living in the house $(p=0.025)$, medium through which households were educated about proper solid waste management $(p<0.0001)$, enforcement of proper of bi-laws $(p=0.005)$, type of solid waste generated $(p<0.0001)$ and solid waste storage method $(p=0.009)$ were all significant determinants. Males were 0.5 times less likely to comply with guidelines compared with females (COR: 0.5, Cl: 0.3-0.8). Most of the respondents were either married or cohabiting and that being of this marital status had 0.5 times less chances of complying with guidelines (COR: $0.5, \mathrm{Cl}: 0.3-0.9$ ). Being of secondary, tertiary and the never schooled group, had 5.9, 4.7 and 3.1 times more chances of complying with guidelines compared with primary level of education respectively (COR: 5.9, $\mathrm{Cl}$ (0.6-54.7); COR: 4.7, $\mathrm{Cl}$ (2.5-9.2); COR: 3.1, $\mathrm{Cl}(1.9-5.1))$. Households with 5-10 and those with more than 10 people were 1.8 and 1.3 times more likely to comply with guidelines compared with households with less than five people (COR: 1.8, $\mathrm{Cl}(1.2-2.7)$; $\mathrm{COR}: 1.3, \mathrm{Cl}(0.2-7.9)$ ).

From key informant interviews presence of bi-laws was a determinant. One key informant said, "[...] we held several community meetings to deliberate on solid waste management and came up with bilaws which our members owned and are happy to abide by: for example, every household is required to have a sac or polythene bag to store their solid waste before the truck picks the waste [...]".

\subsection{Attitudes of Participants about Household Solid Waste Management in Compliance With Guidelines}

Attitudes were examined and scored on a Likert scale with highest score of five, for 'very appropriate', and lowest score of one, for 'very inappropriate' attitudes. Respondents who scored an average of 4 and above were considered to have enabling attitudes to comply with guidelines, table 5 .

Majority of households $(62.5 \%$, ) indicated that it was appropriate to carry a shopping bag whenever they went shopping, and only one respondent $(0.3 \%)$ thought that it was very inappropriate. $53.8 \%$ indicated that it was appropriate to recycle. For the rest, majority thought it was not so appropriate to separate 
(49.9\%), re-use $(53.7 \%)$ and compost waste $(57.1 \%)$ respectively. Hence, the only practices in which participants had enabling attitudes with their mean score close to 4 were; waste reduction, with $64.6 \%$ responses scoring a mean of approximately 4 and waste recycling (65.2\%).

Table 5: Attitudes of Households about Compliance with Guidelines

\begin{tabular}{|c|c|c|c|c|c|c|}
\hline Attitudes & $\begin{array}{l}\text { Very } \\
\text { appropri }\end{array}$ & $\begin{array}{l}\text { Appropri } \\
\text { ate-ate }\end{array}$ & $\begin{array}{l}\text { Not so } \\
\text { appropriat }\end{array}$ & $\begin{array}{l}\text { Inappropri } \\
\text { ate }\end{array}$ & $\begin{array}{l}\text { Very } \\
\text { inappropriate }\end{array}$ & $\begin{array}{l}\text { Mean } \\
\text { (SD) }\end{array}$ \\
\hline - Attitudes about taking & $\begin{array}{l}\text { ate-ate } \\
8(2.1)\end{array}$ & & $\begin{array}{l}\text { e-ate } \\
127(33.1)\end{array}$ & $8(2.1)$ & $\begin{array}{l}\text {-ate } \\
1(0.3)\end{array}$ & $3.6(0.6)$ \\
\hline $\begin{array}{l}\text { a shopping bag when } \\
\text { you go shopping }\end{array}$ & & & & & & \\
\hline $\begin{array}{l}\text { - Attitudes about solid } \\
\text { waste separation }\end{array}$ & $16(4.2)$ & $170(44.4)$ & 191(49.9) & $6(1.6)$ & $0(0)$ & $3.5(0.6)$ \\
\hline $\begin{array}{l}\text { Attitudes about re-use } \\
\text { of some solid waste }\end{array}$ & $5(1.3)$ & $160(41.9)$ & $205(53.7)$ & $12(3.1)$ & $0(0)$ & $3.4(0.6)$ \\
\hline $\begin{array}{l}\text { Attitudes about } \\
\text { recycling }\end{array}$ & 44(11.4) & $207(53.8)$ & $122(31.7)$ & $12(3.1)$ & $0(0)$ & $3.7(0.7)$ \\
\hline $\begin{array}{l}\text { - Attitudes } \\
\text { composting } \\
\text { waste }\end{array}$ & $2(0.5)$ & $76(19.7)$ & $220(57.1)$ & $73(19)$ & $14(3.6)$ & $2.9(0.7)$ \\
\hline
\end{tabular}

\subsection{Other Barriers of Solid Waste Management at Source Affecting Compliance with Guidelines}

Barriers were examined by asking related questions to households, and interviews with key informants who were local council leaders

For the key informant interviews, an interview guide and a mobile phone recorder were used. Codes were generated from which themes emerged and among others, that of barriers: Migrations, both rural-urban and within the city and illegal dumping was a significant challenge to household solid waste management in the city.

Three of the respondents expressed concerns about lack of space to designate as official dump sites which encouraged some individuals to illegally dump waste. All four (4) respondents reported challenges of internal migrations in that some new migrants usually come with varying practices and attitudes towards solid waste management and that it would take them some time to adapt to the community bilaws. A respondent said:

"[...] our community is very congested that even households lack where to temporarily store their waste which sometimes forces them to just throw their wastes anywhere, especially when the KCCA truck spends more than three days without coming to pick the waste [...]"

Barriers to practicing composting of some of the solid waste statistically was significant $(p=0.040)$. Lack of space, knowledge of how to compost and nearby composting facility were among the barriers cited by households. 


\subsection{Discussion}

\subsection{Solid Waste Management Practices at Source Associated with Compliance with Guidelines}

This study found that only $37.9 \%$ of the participants practiced household solid waste management in compliance with guidelines, comparable to findings by Ssemugabo et al. (2020) in which only $41.3 \%$ of the households exhibited proper waste management practices. $63.9 \%$ of households practiced waste reduction and $80.3 \%$ re-use, $12.1 \%$ practiced responsible disposal but $41.2 \%$ irresponsibly burnt waste. This finding is comparable to Aisa (2011) study in which $71 \%$ of households practiced waste reuse, $57.9 \%$ open dumping.Most households $(72.9 \%)$ did not segregate their solid waste, a situation similar to the one in Ssemugabo et al. (2020) study in which $78.8 \%$ households did not segregate their waste.

\subsection{Socio-demographic determinants of Solid Waste Management in Compliance with Guidelines}

Findings from this study revealed that gender $(p=0.007)$, marital status $(p=0.016)$ highest education level of the participants $(p<0.0001)$, major occupation $(p=0.007)$ and number of people living in the household were the significant demographic determinants of compliance with guidelines in the management of household solid waste. Similar determinants were revealed in studies by studies by (Adzawla, et al., 2019, Banga,2011, Ashenafi, 2011, Longe, Longe and Ukpebor, 2009 and Abebaw2008) that indicate that female participants were more likely to comply with guidelines especially on solid waste separation than males and a combination of factors including, family size, age and education of the head of the household determined compliance.

\subsection{Attitudes of Solid Waste Management at Source in Compliance with Guidelines}

Study findings show that the only practices with enabling attitudes were waste reduction, $64.6 \%$, and waste recycling (65.2\%), both with mean score 4 . Most waste management practices received a 'not so appropriate attitude', which was not enabling compliance with guidelines.

These findings are consistent with those from a study byBanga (2011), that revealed that about $60 \%$ of respondents had negative attitude and not in support of waste segregation or recycling and majority not bothered about dumping (Blakely and Leigh, 2010). On the contrary, a study by Mukama et al. (2016) in Kampala slums found a high percentage of respondents indicating willingness to segregate $(76.6 \%)$ and compost (54.9\%) solid wastes. 


\subsection{Other Barriers of Solid Waste Management at Source in Compliance with Guidelines}

Findings from this study show that major barriers to compliance with guidelines in household solid waste management from key informant interviews were; lack of awareness, space, infrastructural (poor housing and congested settlements), technical (inability to segregate), irregularities in waste collection and rampant internal migrations. Among the studied practices, barriers to composting were statistically significant $(\mathrm{p}=0.040): 24.2 \%$ of the respondents did not know how to compost, $16.6 \%$ lacked space, $24.55 \%$ lacked both space and knowledge of composting. This finding is in agreement with that of McAllister (2015) that foundout that inadequate education and awareness about proper solid waste management led to irresponsible practices that encourage noncompliance with solid waste management reforms and guidelines. Mamady (2016), noted that majority of respondents (53.7\%) whose residence was in unplanned areas mainly practiced open dumping. Another study by (Nachalida, Beverly and Kirstin, 2017) observed that irregularities in waste collection by authorities or private waste collectors adds to the barriers in that households who manage to sort their waste in bins get stuck with it for days or weeks which compels them to dump illegally.

\subsection{Conclusion}

Compliance with guidelines in the management of household solid waste at source is still very low even in a municipality within the capital city and yet, proper practice of such basic social actions is very essential for the transformation of lives of the city dwellers. Noncompliance with guidelines leads to poor solid waste management which has been associated with diseases of unhygienic conditions like Cholera and environmental degradation through water and air pollution with consequent reduction in the biodiversity. This reduces the quality of life of the residents affecting their social and economic productivity due to ill health, and hence a vicious cycle of poverty. On the other hand, for a developing city like Kampala, residents scoring low on basic social skills, delays transition into a modern city. This deters potential foreign investments in the city and reduces foreign exchange and earnings, and ultimately affects national development.

\section{Declarations}

\section{ACKNOWLEDGEMENT}

The author acknowledges and appreciates support from Kawempe division public health officials and local council leaders during data collection, and all our respondents.

\section{CONTRIBUTORSHIP}

MP conceptualized the study, wrote the proposal and collected the data. 
OK supervised the study, curated the study design, analyzed and interpreted the results, drafted the manuscript and addressed all correspondences related to the study.

\section{AUTHORS' INFORMATION}

MP is an MPH Student with Uganda Martyrs University, department of Health Sciences.

OK is a Medical Doctor and Lecturer in the Faculty of Health Sciences (FHS) of Uganda Martyrs University, Kampala. He holds a PhD in Mgt [Healthcare Mgt], Master of Science in Health Services Mgt (MSc. HSM), Master of Science in Monitoring and Evaluation (MSc. M \& E), Post Graduate Diploma in Project Planning and Mgt (PGD PPM), Post Graduate Certificate in Project Monitoring and Evaluation (PGC M \& E), and Bachelor of Medicine and Bachelor of Surgery (MBChB) degree. He is currently engaged in teaching Public Health and Health Services Management at graduate and post-graduate levels, research supervision in the said areas and levels and community engagement, among others.

\section{Funding}

No external funding was granted for this study.

\section{Conflict of Interest Disclosure}

The authors declare no conflict of interest.

\section{Consent for Publication}

The authors do consent for publication of this work.

\section{Data Availability}

All data related to the study is available with the corresponding author and can be accessed on reasonable request.

\section{References}

1. Abebaw, D., 2008. Determinants of Solid Waste Disposal Practices in Urban Areas of Ethiopia: A Household-Level Analysis, East African Social Science Research Review, Vol. 24 No. 1: Pp 1-14. [online] Available at:< DOI:10.1353/eas.2008.0000 > [accessed 7/July/2021].

2. Adzawla, W., Tahidu, A., Mustapha, S. and Azumah, S. B., 2019. Do socioeconomic factors influence households' sold waste disposal systems? Evidence from Ghana, Waste Management and Research, Vol. 37, No. 1, Supplement 51-57. [online] Available at:< DOI: 10.1177/0734242X18817717> [accessed 20/July/2021].

3. Aisa, O. S., 2011. The role of households in solid waste management in East Africa Capital cities. PhD. Wageningen University. 
4. Al-Khatib, I. A., Arafat, H.A., Daoud, R., and Shwahneh, H., 2009. Enhanced solid waste management by understanding the effects of gender, income, marital status and religious convictions on attitudes and practices related to street littering in Nablus-Palestinian territory. Waste Management, Vol. 29, issue 1, Pp 449-455 [online] Available at:

https://www.scirp.org/(S(351jmbntvnsjt1aadkposzje))/reference/ReferencesPapers.aspx? ReferencelD $=1752377$ [accessed 12/September/2020].

5. Aryampa, et. al., 2019. Status of Waste Management in the East African Cities: Understanding the Drivers of Waste Generation, Collection and Disposal and Their Impacts on Kampala City's Sustainability, Sustainability, [online], Available at: https://doi.org/10.3390/su11195523 [Accessed 10 October 2020].

6. Ashenafi, H., 2011. Determinants of Effective Household Solid Waste Management Practices: The Case of Ambo Town - West Showa Zone, Thesis. Mekelle University.

7. Banga, M., 2011. Household Knowledge, Attitudes and Practices in Solid Waste Segregation and Recycling: The Case of Urban Kampala, Zambia Social Science Journal, Vol. 2, No. 1, article 4 [online] Available at: http://scholarship.law.cornell.edu/zssj/vol2/iss1/4 [Accessed 24/July/2021].

8. Bello, et. al., 2016. Solid Waste Management in Africa: A Review, International Journal of Waste Resources, Vol. 6, No. 2, [online] Available at: DOI: 10.4172/2252-5211.1000216 [Accessed 20/October/2020].

9. Blakley, E. J., and Leigh, N.G, 2010. Planning Local Economic Development: Theory and Practice $\left(4^{\text {th }}\right.$ ed $)$. Thousand Oaks, CA. Available at: DOI:10.1177/0891242410374959 [Accessed 10/February/2021].

10. Cochran, W. G., 1977. Sampling Techniques. $3^{\text {rd }}$ ed [PDF] New York. John Wiley and Son. Available at: https://glad.geog.umd.edu/Potapov/_Library/Cochran_1977_Sampling_Techniques_Third_Edition.pdf [accessed 10/October/2020].

11. Cruvinel, V.R.N., Marques, C.P., Cardoso, V., et al., 2019. Health conditions and occupational risks in a novel group: waste pickers in the largest open garbage dump in Latin America. BMC Public Health 19, 581 [online] available at:https://doi.org/10.1186/s12889-019-6879-x

12. Ishfaq, S., Puneet P., and Sukhwinder P., 2021. Implementation analysis of solid waste management in Ludhiana city of Punjab, Environmental Challenges, Volume 2, 100023 [online] Available at https://doi.org/10.1016/j.envc.2021.100023. [Accessed 10/June/2021]

13. Komakech, A.J., Banadda, N.E., Kinobe, J.R., Kasisira, L., Sundberg, C., Gebresenbet, G., Vinnerås, B., 2014. Characterization of municipal waste in Kampala, Uganda. J. Air Waste Manag. Assoc., [online] Available at: https://doi.org/10.1080/10962247.2013.861373 [Accessed 10 October 2020].

14. Longe, E. O., Longe, O.O. and Ukpebor, E. F., 2009. People's Perception on Household Solid Waste Management in Ojo Local Government Area in Nigeria Iran. J. Environ. Health. Sci. Eng., Vol. 6, No. 3, Pp. 2001-208. [online] Available at http://www.bioline.org.br/pdf?se09031 [accessed 25/July/2021].

15. Mamady. K., 2016. Factors Influencing Attitude, Safety Behavior, and Knowledge regarding Household Waste Mnanagement in Guinea: A Cross-Sectional Study, Journal of Environmental and Public 
Health, Volume 2016, ID 9305768 [online] available at: http://dx.doi.org/10.1155/2016/9305768 [Accessed 12/June/2021].

16. McAllister, J. 2015. Factors Influencing Solid-Waste Management in the Developing World, All Graduate Plan B and other Reports, Volume 528 P 32. [online] available at: https://digitalcommons.usu.edu/gradreports/528 [Accessed 10/June/20].

17. Mukama, T., Ndejjo, R., Musoke, D., Musinguzi, G., Halage, A.A., Carpenter, D.O., Ssempebwa, J.C., 2016. Practices, Concerns, and Willingness to Participate in Solid Waste Management in Two Urban Slums in Central Uganda, J. Environ. Public Health, [online] available at: https://doi.org/10.1155/2016/6830163. [Accessed 10/October /2020].

18. Nachalida, Y., Beverly, C. and Kirstin, R., 2017. Barriers to Effective Municipal Solid Waste Management in a Rapidly Urbanizing Area in Thailand, Int. J. Environ. Res. Public Health, 14, 1013 [online] Available at: doi:10.3390/ijerph14091013[Accessed 28/June/2021].

19. Ssemugabo. C., Wafula. S. T., Lubega. G. B., Ndejjo. R., Osuret. J.,Halage. Et al., 2020. Status of Household Solid Waste Management and Associated Factors in a Slum Community in Kampala, Uganda, Journal of Environmental and Public Health, Volume 2020, ID 6807630. [online] Available at: https://doi.org/10.1155/2020/6807630. [Accessed 30/June/2021]

20. Wadehra S. and Mishra A., 2017. Managing waste at the household level: Field evidence from Delhi. International growth center, London C-35324-INC-1. [online] Available at: https://www.theigc.org/wpcontent/uploads/2017/10/Wadehra-et-al-Final-report_cover.pdf

\section{Supplementary Files}

This is a list of supplementary files associated with this preprint. Click to download.

- AppendixlQuestionaire.docx

- AppendixllObservationChecklist.docx

- AppendixIIIKIIGuide.doc 